\begin{tabular}{ll}
\hline Homepage: http:/jusami.batan.go.id & Jurnal Sains Materi Indonesia \\
\hline & $\begin{array}{l}\text { Akreditasi LIPI } \\
\text { No.: 602/AU3/P2MI-LIPI/03/2015 } \\
\text { Tangal 15 April 2015 } \\
\text { ISSN : 1411-1098 }\end{array}$ \\
\hline
\end{tabular}

\title{
MICROSTRUCTURE AND PHASE TRANSFORMATION OF PURE TITANIUM DURING NITRIDING PROCESS BY HIGH DENSITY PLASMA
}

\author{
J.M. Windajanti ${ }^{1,2}$, D.J.D.H. Santjojo ${ }^{1}$ and Abdurrouf ${ }^{1}$ \\ ${ }^{1}$ Jurusan Fisika, FMIPA - Universitas Brawijaya \\ Jl.Veteran 2, Malang 65145 \\ ${ }^{2}$ SMAK Santa Maria \\ Jl. Raya Langsep 41, Malang, 65116 \\ E-mail: joce_win@yahoo.com
}

Received: 3 January $2017 \quad$ Revised: 24 March $2017 \quad$ Accepted: 6 April 2017

\begin{abstract}
MICROSTRUCTURE AND PHASE TRANSFORMATION OF PURE TITANIUM DURING NITRIDING PROCESS BY HIGH DENSITY PLASMA. Low temperature nitriding process at a temperature of $450{ }^{\circ} \mathrm{C}$ has been carried out in order to increase the surface hardness of pure titanium. The plasma nitriding process was utilized by high density RF-DC system with an addition of a hollow cathode device. The plasma was generated by RF generator with the frequency of $2 \mathrm{MHz}$ and attract directly to the cathode plate by high voltage DC bias of -500 to $-600 \mathrm{~V}$. The plasma of $\mathrm{N}_{2} / \mathrm{H}_{2}$ gases with a flow rate of $160 / 40 \mathrm{~mL} / \mathrm{min}$ in gas pressure of 75, 50, and $30 \mathrm{~Pa}$ was used in nitriding process for $4 \mathrm{~h}$ and $8 \mathrm{~h}$. The occurrence of phase transformation of -Ti to w-Ti triggers the formation of TiN as a nitride layer. The formation of TiN and the diffusion of nitrogen into a titanium matrix can increase the surface hardness of pure titanium up to $792.0 \mathrm{HV}$.
\end{abstract}

Keywords: Pure titanium, RF-DC plasma system, Low temperature nitriding, Omega titanium, Increasing surface hardness

\begin{abstract}
ABSTRAK
STRUKTURMIKRO DAN TRASFORMASI FASA TITANIUM SELAMA PROSES NITRIDASI DENGAN HIGH DENSITY PLASMA. Proses nitriding pada suhu $450{ }^{\circ} \mathrm{C}$ berhasil dilakukan untuk meningkatkan tingkat kekerasan logam titamium murni. Proses nitriding menggunakan plasma berdensitas tinggi yang dihasilkan oleh sistem RF-DC dengan penambahan perangkat hollow cathode. Plasma dibangkitkan oleh RF generator yang berfrekuensi $2 \mathrm{MHz}$ dan ditarik menuju plat katoda oleh tegangan tinggi suatu bias DC sebesar $-500 \mathrm{~V}$ atau $-600 \mathrm{~V}$. Plasma yang terbentuk dari campuran gas nitrogen dan gas hidrogen dengan laju aliran sebesar 160/40 mL/menit pada tekanan gas sebesar 75, 50, dan $30 \mathrm{~Pa}$ digunakan pada proses nitriding selama 4 jam atau 8 jam. Hasil yang didapat adalah terjadinya perubahan fase dari $\alpha$-Ti menjadi $\omega$-Ti yang sekaligus menjadi pemicu terbentuknya TiN sebagai lapisan nitride. Pembentukan TiN dan terjadinya difusi dari atom nitrogen ke dalam matriks logam titanium berhasil meningkatkan kekerasan permukaan logam titanium hingga mencapai nilai 792,0 HV.
\end{abstract}

Kata kunci: Titanium murni, Sistem plasma RF-DC, Nitriding pada suhu rendah, Omega titanium, Peningkatan kekerasan permukaan

\section{INTRODUCTION}

For the last few decades, titanium has attracted tremendous interest in many fields of industry, such as aerospace, industrial, consumer applications, and production of implants [1-3]. It because titanium is a lightweight metal owing to such properties as low density, high corrosion stability, and biocompatibility $[1,4,5]$. However, the low surface hardness, high friction coefficient, and low wear resistance prevent the use of 
titanium in friction pairs restrict their use of application where sliding is inevitable [6].

The crystal structure of titanium at ambient temperature and pressure is close-packed hexagonal $(\alpha)$ with a c/a ratio of 1.587 . At $883{ }^{\circ} \mathrm{C}$, this transform to a body-centered cubic $(\beta)$ which is stable to the melting point [5]. The mechanical properties of titanium depend on the phases present. The hexagonal alpha is relatively soft, tough, and ductile, whereas the beta is harder, stronger but less ductile. A metastable phase of a simple hexagonal structure known as $\omega$-phase can form if a high pressure is induced to $\alpha$-phase $[7,8]$. It has been proposed that a displacement of (1210) planes lying in the (0001) plane in $\alpha$-phase resulting from the propagation of a lattice displacement wave through the crystal involving atomic shuffles resulted in the transition $[9,10]$.

In order to improve such properties, one promising way of titanium surface engineering is through the formation of titanium nitride (TiN) on the top surface $[6,11]$. Nowadays, there is a growing interest in the methods of thermo-chemical treatment with diffusion saturation of material surface by an element such as nitrogen [12]. The nitriding process of titanium typically involves a high temperature of $700-1000{ }^{\circ} \mathrm{C}$ which can harden the surface material up to $1300 \mathrm{HV}$ [5,11]. Plasma nitriding is a thermo-chemical method that can control the phase formation and the depth of the nitrided layer [3-5,13]. It also requires short periods of nitriding time and can avoid oxidation, but the high temperature in the process can reduce the fatigue strength and cause detrimental micro-structural changes in titanium substrates [5].

The present work proposes a simple method for the efficient nitriding with the aim of enhancing the physical properties of titanium by modifying the surface microstructure through nitriding using RF-DC plasma treatment. An additional device of the hollow cathode tube [14] is used to reduce the temperature process into $450{ }^{\circ} \mathrm{C}$. The gas pressure and DC bias were controlled as process parameters in order to gain the optimum result of the low temperature plasma nitriding process [15]. The purpose of this study was to determine how the influence of the phase change that occurs in titanium that allows the formation of TiN as an agent that can cause the increasing of surface hardness $[4,6,10]$ of titanium at the low temperature plasma nitriding process.

\section{EXPERIMENTAL METHOD}

\section{Tools and Materials}

Pure titanium plates were used as samples for the nitriding process. The samples were cut into $18 \times 40 \times 0.3$ $\mathrm{mm}^{3}$ pieces with a precision cutter. They were ultrasonically cleaned in an industrial soap (alkali solution), rinsed and then dried with ethanol.
A plasma system using an RF - DC generator is utilized for conducting a low temperature nitriding process. The RF generator has the frequency of around $2 \mathrm{MHz}$, which is controlled by the automatic matching power condition. This system consists of a vacuum chamber, a computerized control unit, a plasma generator, a gas supply sub-system, and a vacuum pump system. Inside the vacuum chamber, there was a pair of RF dipole rod electrodes, a stainless plate of DC bias cathode, and a resistive heater under the cathode plate. Gas pressure, RF voltage, DC bias voltage, and cathode plate temperature were controlled by a processing unit. In the present investigation, an addition of a stainless steel hollow cathode tube was used and placed on the cathode plate with stainless steel buffer cylinders. Nitrogen and hydrogen gasses were injected into the chamber through a nozzle placed in front of the hollow cathode tube. The RF-DC plasma system in this experiment can be seen in Figure 1 below.

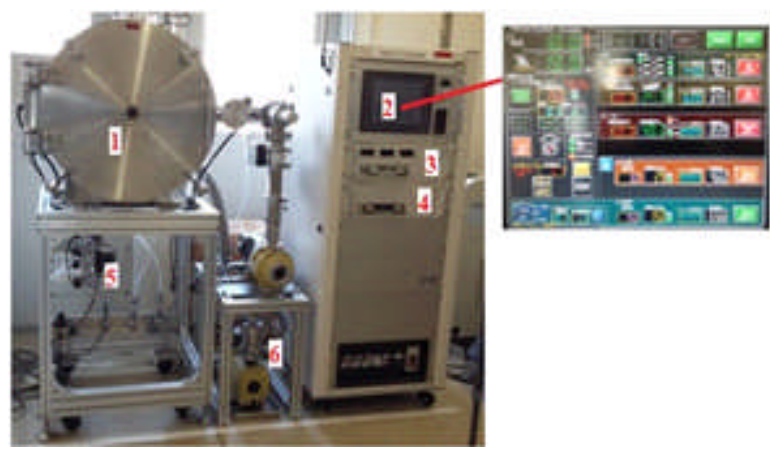

Figure 1. The high density RF-DC plasma system consists of (1). vacuum chamber, (2). control panel, (3). RF power generator, (4). DC bias power generator, (5). carrier gas supply and (6). vacuum pump system [16]

After the nitriding process had been carried out, the surface hardness of nitrided specimen was measured by a micro-Vickers hardness Akashi MVK-H1 tester with an applied load of $0.5 \mathrm{~N}$ or $50 \mathrm{gf}$. The surface hardness was obtained by averaging the data from five different positions area. The surface microstructure of the nitrided titanium specimens was observed by a scanning electron microscope (SEM, Shimadzu SSX-550M). Cross-sectional cuttings were analyzed by SEM and EDX. The phase analysis of nitrided surface was carried out by an X-ray diffraction (XRD) system using Rigaku Ultima IV. A monochromated $\mathrm{Cu} \mathrm{K \alpha}$ radiation $(\lambda=1.54598 \AA$ ) was used for this study. The phases were identified through the comparison of the obtained data with lattice parameters cited from ICSD\#44390 for $\alpha$-titanium, ICSD\#52521 for $\omega$-titanium and ICSD\#152807 for titanium nitride, respectively.

\section{Plasma Nitriding Process}

After specimen and chamber preparation, the assembly of titanium specimen inside the hollow tube 
was loaded into the chamber and placed on the cathode plate. Initially, the system was pumped down to the base pressure of $0.7 \mathrm{~Pa}$ in order to remove oxygen gas from the chamber. After that, nitrogen gas was introduced into the chamber, and the specimen was heated up to $450{ }^{\circ} \mathrm{C}$ in a nitrogen atmosphere with the pressure of $300 \mathrm{~Pa}$. The gas was flown by the nozzle gas that's placed in front of the hollow tube. Once the specimen temperature has reached $450{ }^{\circ} \mathrm{C}$, the chamber pressure was lowered back to set-up process pressure, and then the plasma was ignited. After the plasma ignition, the higher density plasmas are formed inside the metal tube due to the pressure gradient between inside and outside the metal tube.

In this study, several process parameters were set to obtain optimum results. The set-up parameters that were chosen to present low temperature nitriding process can be summarized in Table 1.

Table 1. Set-up value of plasma nitriding processing parameters

\begin{tabular}{ll}
\hline \multicolumn{1}{c}{ Processing Parameter } & \multicolumn{1}{c}{ Set-up Value } \\
\hline Base pressure of vacuum chamber & $0.7 \mathrm{~Pa}$ \\
Temperature process & Fixed at $450{ }^{\circ} \mathrm{C}$ \\
RF voltage & $250 \mathrm{~V}$ \\
DC bias voltage & Variance at $-500 \mathrm{~V}$ and \\
& $-600 \mathrm{~V}$ \\
Mixed gas flow rate & $160 \mathrm{ml} / \mathrm{min}_{2}$ and \\
& $40 \mathrm{ml} / \mathrm{min}_{2}$ \\
Pressure of mixed gas & Variance at $75 \mathrm{~Pa}, 50$ \\
& Pa, and $30 \mathrm{~Pa}$ \\
Processing time & $4 \mathrm{~h}$ and $8 \mathrm{~h}$ \\
\hline
\end{tabular}

There are two important stages in this nitriding process. First, the pre-nitriding process was carried out using plasma that generated by a DC generator with a high voltage of $-500 \mathrm{~V}$. At this stage, the plasma of the gas mixture of nitrogen and hydrogen with a flow rate of 160/40 $\mathrm{ml} / \mathrm{min}$ was utilized in $1 \mathrm{~h}$. The plasma ion in high voltage was used to sputter the surface of specimens in order to remove titanium oxide from the outermost surface [4,17]. Meanwhile, a surface activation process was also carried out before the main nitriding process.

Secondly, the primary nitriding process, in which is the specimen was exposed to a plasma which is generated by a combination of RF and DC power. In this experiment, the RF voltage was set at maximum value of $250 \mathrm{~V}$. Meanwhile, the DC bias voltage was set at a high value of $-500 \mathrm{~V}$ or $-600 \mathrm{~V}$. The high DC bias voltage is required, in order to attract the positive plasma ions toward the cathode plate, to get the high energy collisions between plasma ions and the specimen surface. An addition of the hollow cathode device was used to gain the higher intensity plasma by the plasma trapping process. The potential differences between the outside and the inside of the hollow tube resulted in the formation of a very high-intensity plasma inside the hollow tube [18]. The main process was carried out with a processing time of $4 \mathrm{~h}$ or $8 \mathrm{~h}$.
In an effort to gain an increase of the surface hardness of titanium samples in this nitriding process, the use of a relatively low gas pressure was also required. The combination of high voltage DC bias with a gas pressure variation with a respective value of $75 \mathrm{~Pa}, 50$ $\mathrm{Pa}$, and $30 \mathrm{~Pa}$ selected to produce the optimum surface hardness. After the nitriding process was completed, the specimen temperature was lowered in a nitrogen atmosphere at $75 \mathrm{~Pa}$ until it reaches a value of $300{ }^{\circ} \mathrm{C}$, and then it was cooled again to $150{ }^{\circ} \mathrm{C}$ before the chamber was opened.

\section{RESULT AND DISCUSSION}

A significant change of surface morphology of nitrided specimen has occurred after a diffusion process of nitrogen atoms into the titanium lattice in the nitriding process. A striped line structure of titanium top surface was observed by SEM before the nitriding process. This top surface structure turns into a granular structure after the $4 \mathrm{~h}$ nitriding processes by high density RF-DC plasma with a gas pressure of $30 \mathrm{~Pa}$ and DC bias voltage of $-600 \mathrm{~V}$ at a temperature of $450{ }^{\circ} \mathrm{C}$ as depicted in Figure 2.

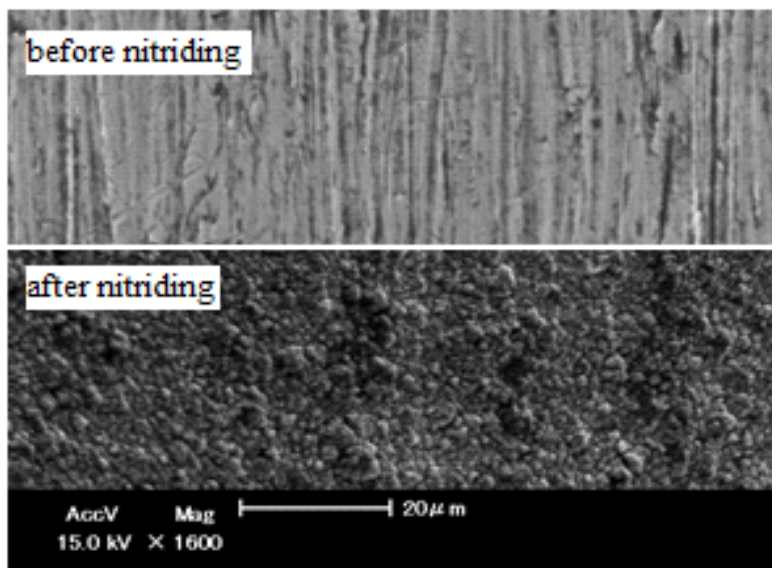

Figure 2. The morphology of top surface microstructure of titanium specimen [19].

The cross-sectional cutting of pure titanium was also observed by SEM is depicted in Figure 3. In every nitrided specimen, a thin layer of the surface part with a thickness of few micrometers was formed at the outermost surface. The EDX analysis observed a thin layer contained the contaminant elements of $\mathrm{Fe}, \mathrm{Cr}$, and Ni that didn't come from titanium alloys. These coated residues on the surface of a pure titanium sample may originate from the stainless steel material of the hollow tube. Below the surface, the nitride layer appeared with a high concentration of nitrogen up to $18.55 \%$ after $4 \mathrm{~h}$ nitriding processes and up to $26.96 \%$ after $8 \mathrm{~h}$ nitriding processes. And, below this layer is the diffusion zone with a matrix of the pure titanium. The diffusion zone was detected to a depth of $6 \mu \mathrm{m}$ and $9 \mu \mathrm{m}$ after $4 \mathrm{~h}$ and $8 \mathrm{~h}$ of the treatment respectively. The increasing of 


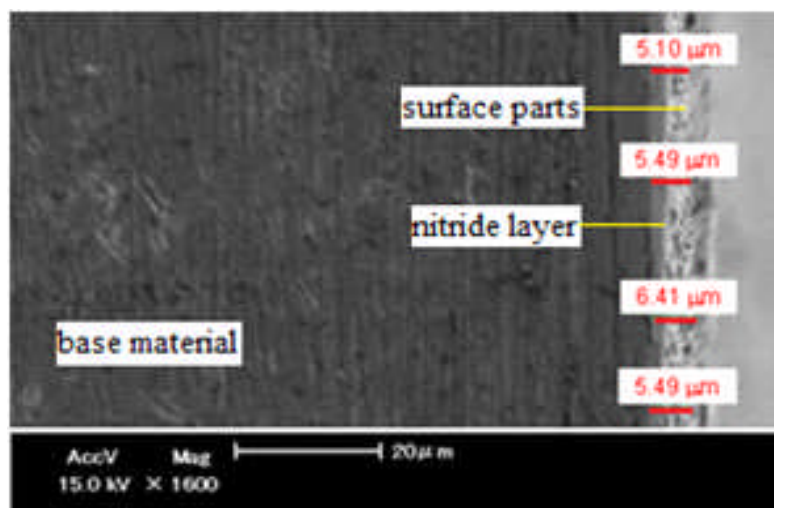

Figure 3. The cross-section microstructure of the nitrided specimen after subjecting to plasma nitriding during for $4 \mathrm{~h}$ processes under DC bias of $-600 \mathrm{~V}$ and at a gas pressure of $30 \mathrm{~Pa}$.

surface part thickness was obtained in the process with a lower gas pressure.

Interesting findings obtained from the low temperature nitriding process on pure titanium using a high density plasma is the phase transformation from $\alpha$-phase of pure titanium into a metastable $\omega$-phase as shown on the XRD pattern of nitrided samples in Figure 4. Moreover, it also found the formation of titanium nitride (TiN), which is important for enhancing the surface hardness of titanium [5-6,20]. In the process using lower pressure, there is the increasing formation of $\omega$-Ti and TiN [15].

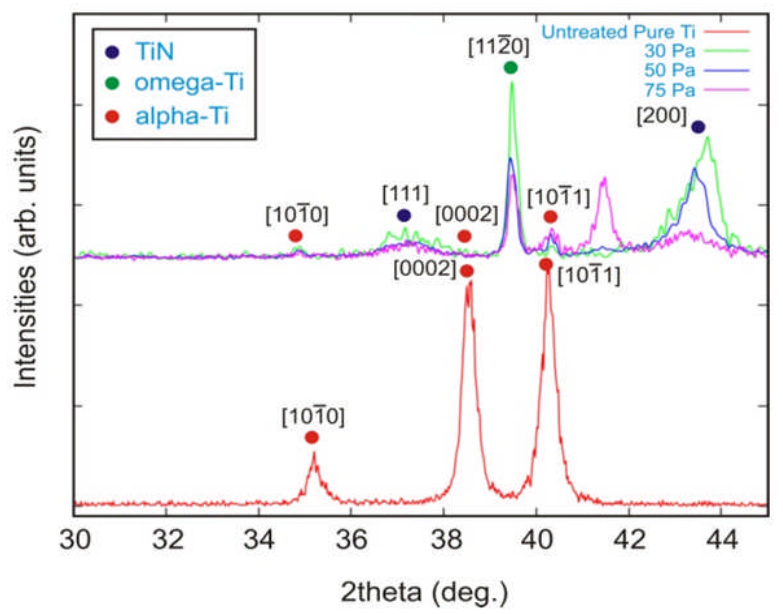

Figure 4. The changing of X-ray diffraction patterns of untreated pure titanium to the nitrided specimen after $4 \mathrm{~h}$ treatment of plasma nitriding under a DC bias voltage of $-600 \mathrm{~V}$ for the different gas pressure of $75 \mathrm{~Pa}, 50 \mathrm{~Pa}$, and $30 \mathrm{~Pa}$.

The untreated pure titanium completely consists of $\alpha$-Ti phase in its microstructure. It was obtained that the peaks of $\alpha$-Ti phase is detected at $35.2^{\circ}, 38.6^{\circ}, 40.3^{\circ}$, $53.1^{\circ}, 63.0^{\circ}, 70.8^{\circ}$ and $76.3^{\circ}$ corresponding to planes with

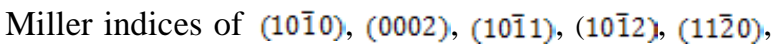
(1013) and $(11 \overline{2} 2)$, respectively, with the highest peak intensity is found in, and planes. At the range of $2 \theta=30^{\circ}$ to $50^{\circ}$, there were significant changes of $\alpha$-Ti peaks after the nitriding process as can be seen in Figure 4. On the nitrided specimens, the peaks of $\alpha$-Ti were decreased dramatically. A peak formation is observed, indicating a new metastable phase of $\omega$-Ti and titanium nitride (TiN) compound layer. In Figure 4, it was clear that $\alpha$-Ti peak at $2 \theta=38.6^{\circ}$ and $40.3^{\circ}$ disappeared and replaced with the new peak of $\omega$-Ti at $2 \theta=39.5^{\circ}$ correspond to $[11 \overline{2} 0]$ plane. Other peaks of $\omega$-Ti were also found at $2 \theta=51.3^{\circ}$ and $70.8^{\circ}$ corresponding to $(1 \overline{2} \overline{1})$ and $(30 \overline{3} 0)$ planes, respectively. The presence of a TiN phase on the nitrided sample is also determined in the XRD surface analysis. The face center cubic (FCC) structure of TiN was detected in new peaks at $2 \theta=37.2^{\circ}, 43.4^{\circ}, 61,5^{\circ}$ and $74.4^{\circ}$ corresponding to (111), (200), (220) and (311) planes, respectively.

The different peak intensity of $\omega$-Ti and TiN formation were observed in the nitrided specimens produced by using DC bias of $-500 \mathrm{~V}$ and $-600 \mathrm{~V}$ with the gas pressure of $75 \mathrm{~Pa}, 50 \mathrm{~Pa}$, and $30 \mathrm{~Pa}$, respectively. Based on XRD pattern results, the differences in intensity of every observed phase showed the differences of phase concentration. In this study, it was calculated the inter-phase ratio of each phase to determine the dynamics of phase changes that occur during the nitriding process. In the process using lower pressure, the concentration of $\alpha$-Ti phase tends to decrease while the concentration of $\omega$-Ti phase tends to increase. The calculation of $\omega$-Ti phase and TiN phase is depicted in Figure 5.

\section{$\omega$-Ti phase concentration (\%)}

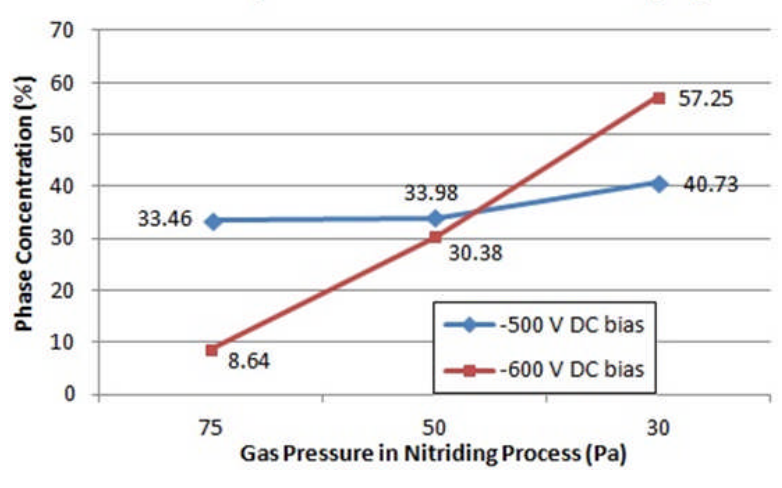

TiN compound concentration (\%)

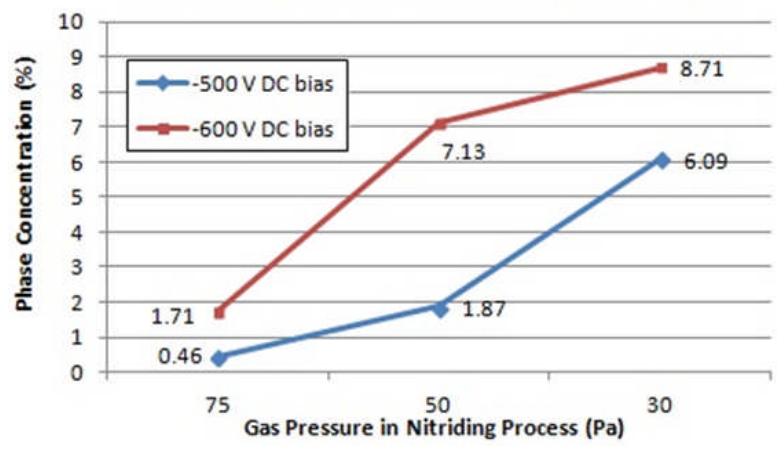

Figure 5. The calculation of $\omega$-Ti phase and TiN phase concentration in nitrided pure titanium 
For example, the concentration of $\omega$-Ti increase from $8.64 \%$ to $57.25 \%$ in the nitriding process using DC bias of $-600 \mathrm{~V}$. The formation of $\omega$-phase in the nitrided specimens is driven by lowering the gas pressure of the nitriding process combined with high voltage DC bias. This might be caused by the longer mean free path for activating species in the plasmas resulted from the decrease in pressure [15]. It can be inferred because in the longer mean free path, the recombination of species in plasma will be suppressed, so the ion density will be increased [21]. Hence, more nitrogen atom gave opportunities to penetrate into the depth of titanium specimen, and it can induce the transformation of $\alpha$-phase to the $\omega$-phase by the lattice deformation [10].

Another explanation for the occurrence of phase transformation based on the mechanical process is the transformation of $\alpha$-Ti to $\omega$-Ti is caused by high hydrostatic pressure [8-9]. With the TAO-1 (titanium alpha to omega) mechanism, the $\omega$-phase formation is initiated by the strain and the shear [7-8] of the hexagonal basal plane of $\alpha$-Ti into a honeycomb structure and form hexagonal planes in $\omega$-Ti as shown in Figure 6. The growth of $\omega$-phase in a parent $\alpha$-phase is controlled by the mobility of the interface at a finite temperature under a driving force while the temperature alone does not drive the transformation [8].

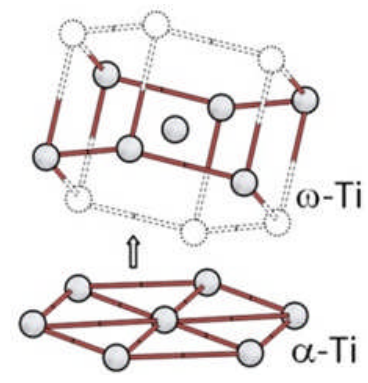

Figure 6. The transformation of the $\alpha$-Ti basal plane to make the hexagonal planes in the -phase [8].

Considering the results of this experiment, we proposed the explanation that can trigger the occurrence of this phase transformation in the nitriding process at a temperature of $450{ }^{\circ} \mathrm{C}$. Compared with the driven force of the formation of $\omega$-phase mechanically, in the plasma nitriding process, it is possibly caused by the hollow cathode effect. According to the geometry of the hollow cathode device, as can be seen in Figure 2, the specimen will be exposed to plasma that has a high density combined with high energy from two different directions, i.e. from above and from the side. The specimen will be exposed to compressive force comes from bombarding titanium atoms by high energy plasma species from two different directions [22]. This situation allows the emergence of torque force that can cause shearing stress. This shear stress is highly possible as a trigger a phase transformation from $\alpha$-Ti to $\omega-\mathrm{Ti}$ [7].

Increasing concentrations of $\omega$-Ti followed by increased concentrations of the TiN compound layer. It can be observed that the decreasing of gas pressure and the increasing of DC bias voltage plays an important role in the formation of compound layer, e.g. the concentration of $\mathrm{TiN}$ fine precipitation increased from $1.71 \%$ to $8.71 \%$ during the process at lower pressure and DC bias voltage of $-600 \mathrm{~V}$. The most important factor that determines the formation of $\mathrm{TiN}$ as the compound layer is the effectiveness of diffusion process onto the surface of titanium specimen that occurs in the nitriding process [3].

The formation of TiN phase is dependent on the availability and the value of nitrogen ion energy when arriving at the specimen surface $[14,15]$. It should be noted here, that the use of low-pressure discharge of the nitriding process can enhance the formation of TiN due to the high density of plasma ions in the low gas pressure. If nitrogen with high concentration diffused rapidly to the surface of the material, saturation will be more quickly formed, so that there will be a bond between the titanium atoms with the nitrogen atoms to form a compound layer of TiN [3,20]. In addition, the use of high DC bias voltage will also greatly affect the effectiveness of diffusion processes because the accelerated ions and fast neutral have high energy at higher voltage [17]. In the process with a DC bias voltage of $-600 \mathrm{~V}$, the saturation condition occurred earlier than the similar process at a DC bias of $-500 \mathrm{~V}$. It was obtained that the formation of TiN increased significantly began at a pressure of $50 \mathrm{~Pa}$ in the process with DC bias of $-600 \mathrm{~V}$ whereas this condition recently occurred at a pressure of $30 \mathrm{~Pa}$ in the process with DC bias of $-500 \mathrm{~V}$.

On the other hand, it can also be argued that the phase transformation from $\alpha$-Ti to the $\omega$-Ti also improve the effectiveness of TiN formation [10]. One explanation may be mentioned here is the result of a calculation on crystal structure models of $\alpha$-Ti and $\omega$-Ti (calculating with CrystalMaker software) which stated that the percentage of void space increase from $79.96 \%$ in $\alpha-\mathrm{Ti}$ phase to $89.74 \%$ in $\omega$-Ti phase. This leads to the high possibility of nitrogen diffusion in the interstitial site. The larger sites have lower formation energies, so the interstitial site formation energy in $\omega$-phase was slightly lower than in $\alpha$-phase [9]. And, it can be inferred that the open structure of $\omega$-Ti phase causes more and more nitrogen atoms to diffuse in the titanium crystal.

Compared with the $4 \mathrm{~h}$ time processing which is carried out at the same gas pressure of $30 \mathrm{~Pa}$ and DC bias voltage of $-600 \mathrm{~V}$, in a long time of $8 \mathrm{~h}$, The formation of TiN increases significantly in the long process of $8 \mathrm{~h}$ while the interphase concentration $\omega$-Ti was decreased. The concentration of the $\omega$-Ti phase decreases from $57.25 \%$ to $37.11 \%$, but the concentration of TiN phase increase significantly from $8.71 \%$ to $38.10 \%$. The XRD pattern that reflects the different intensity of $\omega$-phase and $\mathrm{TiN}$ in the process during $4 \mathrm{~h}$ and $8 \mathrm{~h}$, is depicted in Figure 7. 


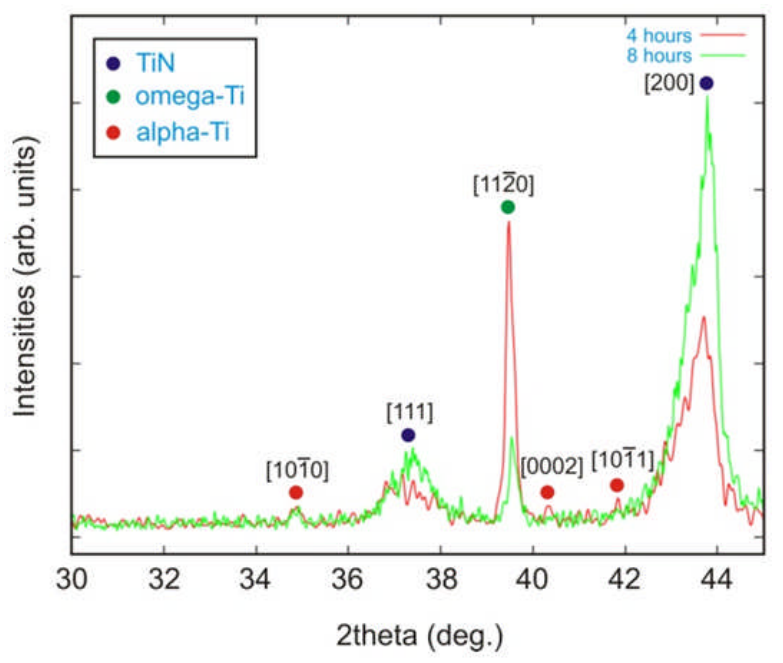

Figure 7. The X-ray diffraction patterns of the nitrided specimen after processing with plasma nitriding during 4 $\mathrm{h}$ and $8 \mathrm{~h}$ under a DC bias voltage of $-600 \mathrm{~V}$ at a gas pressure of $30 \mathrm{~Pa}$

That situation was clearly evident in Figure 7 that the peak intensity of $\omega$-Ti at [11̄20] plane decreased significantly followed by the increasing of the peak intensity of TiN compound correspond with [200] plane. This condition occurs due to the saturation condition just started on the lasted process about $4 \mathrm{~h}$, which is characterized by the low concentration of TiN [3].

The tendency of formation of TiN layer is comparable to an increase in surface hardness [5]. This is in accordance with the data resulting increase in surface hardness, which is depicted in Figure 8. From these data, it appears that the surface hardness of nitrided samples increases with increasing concentration of TiN [3-4,6].

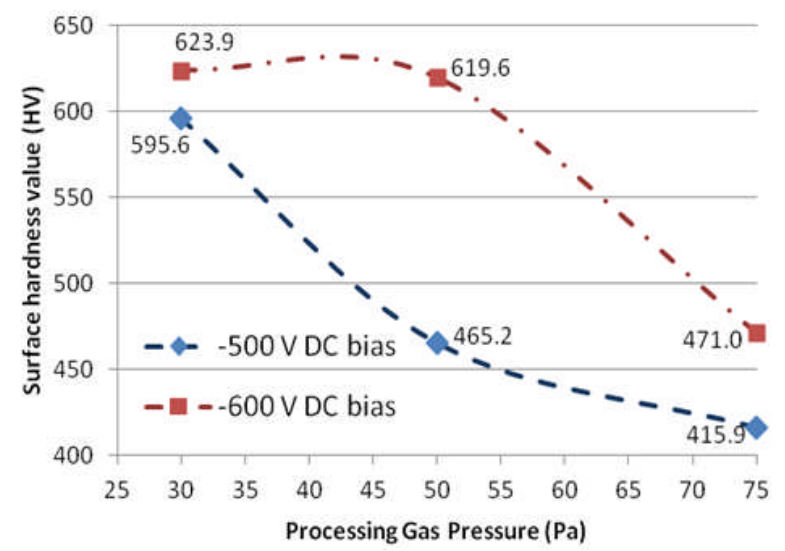

Figure 8. The relationship between the gas pressure to the surface hardness level of nitrided specimen

Besides influenced by the value of the gas pressure and DC bias voltage, the length of time the process would also affect to the increase in the surface hardness $[3,5]$. This is shown by the results of nitriding process is carried out for $8 \mathrm{~h}$ at a temperature of $450{ }^{\circ} \mathrm{C}$, the surface hardness values reached a high of $792.0 \mathrm{HV}$, while at the $4 \mathrm{~h}$ process, the surface hardness level only reached $623.9 \mathrm{HV}$. The occurrence of this increase is in accordance with the above discussion [3].

\section{CONCLUSIONS}

High density plasma generated by RF-DC plasma system was applied to low temperature nitriding of pure titanium at $450^{\circ} \mathrm{C}$. Increased surface hardness of titanium is determined by the use of low gas pressure and high DC bias voltage. The micro-hardness average value amounting to $623.9 \mathrm{HV}$ for loading of $0.05 \mathrm{~N}$ was achieved during the $4 \mathrm{~h}$ processing time in the nitriding process with DC bias $-600 \mathrm{~V}$ at a pressure of $30 \mathrm{~Pa}$, without a phase transition to the BCC structure of $\beta$-titanium. The surface hardness of titanium will increase until it reaches its maximum value of $792.0 \mathrm{HV}$ at a longer processing time of $8 \mathrm{~h}$ with the same process parameters.

The occurrence of titanium phase transformations from $\alpha$-phase to $\omega$-phase encourage the formation of TiN as the nitride layer. Formation of $\omega$-phase could be a trigger for the formation of the TiN phase as it facilitates an increase in the effectiveness of the diffusion process on the specimen nitrided. The use of low pressure in the nitriding process will also accelerate the formation of saturated conditions in the diffusion process of nitrogen atoms into the titanium matrix. Further research is needed to determine the possible use of lower temperature to produce TiN formation in order to increase the surface hardness of titanium using a high-density plasma system.

\section{ACKNOWLEDGEMENT}

The authors wish to thank Prof. Tatsuhiko Aizawa from Shibaura Institute of Technology, Tokyo, Japan, who has provided the opportunity and funding from Jasso Foundation for the author to conduct research in LLC Nanofilm \& Coat Laboratory Japan and for being a good supervisor during the implementation of the research. The authors are also thankful to ASMAT Research Collaboration, University of Brawijaya, which is funded through Program Hibah Kerjasama Luar Negeri JSPS Dikti with the contract number 033/SP2H / LT/DRPM/2/2016, so that this research can be accomplished.

\section{REFERENCES}

[1]. D.K. Peacock. "Titanium." in Construction Materials Reference, $2^{\text {nd }}$ edition. David Doran and Bob Chater, Ed. New York: Routledge, pp. 109-118, 2014.

[2]. L.J. Bartlo and D.J. McNeish. "Mettalography of Titanium and Its Alloys" in Titanium-Physical Metalurgy, Processing and Application, $1^{\text {st }}$ edition. 
F.H. Froes, Ed. Ohio: ASM International, pp. 141-159, 2015.

[3]. Y. Matychak, I. Pohrelyuk, V. Fedirko and O. Tkachuk. "Modelling of Microstructural Evolution of Titanium During Diffusive Saturation by Interstitial Elements" in Titanium Alloys-Advances in Property Control. J. Sieniawski, Ed. (1 ${ }^{\text {st }}$ Edition) InTech. 2013.

[4]. M. Khandaker, S. Riahinezhad, Y. Li, M. B. Vaughan, F. Sultana, T.L. Morris, L. Phinney and K. Hossain. "Plasma Nitriding of Titanium Alloy: Effect Of Roughness, Hardness, Biocompatibility, And Bonding With Bone Cement." Bio-Medical Materials and Engineering, vol. 27, pp. 461-474, 2016.

[5]. E. Koyuncu, F. Kahraman and O. Karadeniz. "Investigation of Surface Properties of HighTemperature Nitrided Titanium Alloys.” Journal of Achievement in Material and Manufacturing Engineering, vol. 37, no. 2, pp. 434-441, 2009.

[6]. X. Wang, S. Bai, F. Li, D. Li, J. Zhang, M. Tian, Q. Zhang, Y. Tong, Z. Zhang, G. Wang, T. Guo, and C. Ma. "Effect of Plasma Nitriding and Titanium Nitride Coating on The Corrosion Resistance Of Titanium." The Journal of Prosthetic Dentistry, pp. 1-7, 2016.

[7]. N. A. Zarkevich and D. D. Johnson. (2015, Oct.). "Titanium $\alpha-\omega$ Phase Transformation Pathway and a Predicted Metastable Structure." Phys Rev B. pp. 1-5, 2017.

[8]. N. Adachi, Y. Todaka, K. Irie, and M. Umemoto. "Phase Transformation Kinetics of $\omega$-phase in Pure Ti Formed by High-Pressure Torsion. J Mater Sci, vol. 51, pp. 2608-2615, 2016.

[9]. R.G. Hennig, D.R. Trinkle, J. Bouchet, S.G. Srinivasan, R.C. Albers, and J.W. Wilkins. "Impurities Block The $\alpha$ to $\omega$ Martensitic Transformation in Titanium." Nature Materials, vol. 4, pp. 129-133, 2005.

[10]. Dehai Ping. "Review on $\omega$ Phase in Body-Centered Cubic Metals and Alloys." Acta Metall. Sin. (Engl. Lett.), vol. 27, no. 1, pp. 1-11, 2014.

[11]. I. Çelik and M. Karakan. "Effect of Plasma Nitriding Treatment on Structural, Tribological And Electrochemical Properties Of Commercially Pure Titanium.” In Proc IMechE Part H: J Engineering in Medicine 1-8, pp. 1-8, 2015.

[12]. Yu F. Ivanov, Yu H. Akhmadeev, I.V. Lopatin, E. A. Petrikova, O. V. Krysina, and N.N. Koval. "Structure and Properties Of Commercially Pure Titanium Nitrided in The Plasma Of A Low-Pressure Gas Discharge Produced by a PINK Plasma Generator." in $12^{\text {th }}$ International Conference on Gas Discharge
Plasmas and Their Applications, IOP Publishing, Journal of Physics: Conference Series 652 (012013), 2015, pp. 1-6.

[13]. I.M. Pohrelyuk, S.E. Sheykin, S.M. Dub, A.G. Mamalis, I.Yu Rostotskii, O.V. Tkachuk, and S.M. Lavrys. "Increasing of Functionality of c.p. Titanium/UHMWPE Tribo-Pairs by Thermodiffusion Nitriding of Titanium Component," Biotribology, vol 7, pp. 38-45, 2016.

[14]. L. Bárdoš. "Radio Frequency Hollow Cathodes for The Plasma Processing Technology." Surface and Coatings Technology, vol. 86-87, pp. 648-656, 1996.

[15]. I.M. Pastukh, N.S. Mashovets, Yu.I. Shalapko and V.A. Kurskaja. "Forecast The Formation of Nitrides on The Surface of Titanium Alloys During Nitriding In A Glow Discharge." Journal of Achievements in Materials and Manufacturing Engineering, vol. 62, no. 2, pp. 53-62. 2014.

[16]. T. Aizawa. Photograph Of The High Density RF-DC Plasma System at LLC Nanofilm \& Coat Laboratory, Ota-ku, Tokyo, Japan. (private communication)

[17]. M. Yoshida, R. Ichiki, and N. Utsumi. "Surface Hardening of Titanium Using Gas Nitriding," J. of Precision Engineering and Manufacturing, vol 14, no, 6, pp. 971-976. 2013.

[18]. E.E. Yunata, T. Aizawa, and D.J.H.D. Santjojo. "Characterization Of Hollow Cathode Plasma for Etching And Ashing Processes." in $8^{\text {th }}$ SEATUC Meeting and Symposium, OS, vol. 6, no. 14, pp. 1-4, 2014.

[19]. J.M. Windajanti, D.J.D.H. Santjojo and Abdurrouf. "Low Temperature Nitriding of Pure Titanium Using Hollow Cathode RF-DC Plasma." IOP Conference Series: Materials Science and Engineering, vol. 202, 2017.

[20]. I. Pohrelyuk and V. Fedirko. "Chemico-Thermal Treatment of Titanium Alloys-Nitriding," in Titanium Alloys-Towards Achieving Enhanced Properties for Diversified Applications, pp.141-174. A.K.M. Nurul Amin, Ed. (1 ${ }^{\text {st }}$ Edition). InTech. 2012.

[21]. H.J. Brading, P.H. Morton, T. Bell, and L.G. Earwaker. "Plasma Nitriding with Nitrogen, Hydrogen, and Argon Gas Mixtures: Structure and Composition of Coating on Titanium." Surface Engineering, vol. 8, no. 3, pp. 206-212, 1992.

[22] A. Gicouel, N. Laidani, P. Saillard, and J. Amouroux. "Plasma and Nitrides: Application to The Nitriding of Titanium.” J. Pure \& Applied Chem., vol. 62, no. 9, pp. 1743-1750, 1990. 